\title{
Histological, immunohistochemical and biochemical study of the effect of triclosan and its withdrawal on cauda epididymis of adult albino rat
}

Original Article

\author{
Reda H. Elbakry and Marwa A. A. Ibrahim
}

Histology and Cell Biology Department, Faculty of Medicine, Tanta University, Egypt

\begin{abstract}
Background: Triclosan (TCS) is a bactericide used in many daily products. TCS potential for endocrine disruption is suspected to impact male reproductive system.

Aim of the study: Is to evaluate the effect of TCS and its withdrawal on the cauda epididymis of adult albino rat using different histological and biochemical techniques.

Materials \& Methods: Twenty-one adult male albino rats were equally divided into 3 groups; control, TCS-treated (administered $200 \mathrm{mg} / \mathrm{kg} /$ day for 8 weeks) and TCS-withdrawal group (administered $200 \mathrm{mg} / \mathrm{kg} / \mathrm{day}$ for 8 weeks then left without treatment for 8 weeks). Serum testosterone was quantified and epididymal specimens were processed for light and electron microscopic examination. Immunohistochemical staining against androgen receptor was performed.

Results: TCS-treated group revealed a significant decrease in serum testosterone. Principal cells showed vacuoles compressing their nuclei, some pyknotic nuclei and sparse stereocilia. Many adluminal halo cells were observed. The epithelial lining depicted focal areas of stratification and areas of discontinuity. Widened interstitium inbetween the ducts with cellular infiltrations and some congested blood vessels were observed. Mallory-trichrome staining revealed prominent collagen fibers surrounding the epididymal ducts and blood vessels and an enhanced Periodic-Acid-Schiff reaction in the thickened basal lamina coupled to a diminished Periodic-Acid-Schiff reaction in the apical parts of the epididymal epithelial cells. A weak nuclear androgen receptor immunoreaction in the epididymal epithelial lining of the ducts was detected. Ultrastructural examination depicted principal cells with irregular nuclei, vacuolated cytoplasm with many lysosomes, dilated Golgi apparatus and rough endoplasmic reticulum. Irregular apical cytoplasmic projections and sparse stereocilia were observed. Clear cells showed some cytoplasmic projections, large apical vacuoles and few lipid droplets. Migrating halo cells with vacuolated cytoplasm were observed. Withdrawal group showed a near normal histology.

Conclusion: TCS has extremely affected the epididymal lining through acting as an endocrine disruptor. Withdrawal of TCS exerted a satisfactory outcome.
\end{abstract}

Received: 25 October 2018, Accepted: 23 November 2018

Key Words: Androgen receptor; electron microscopy; Epididymis; Triclosan; withdrawal.

Corresponding Author: Marwa A. A. Ibrahim, MD, Histology Department, Faculty of Medicine, Tanta University, 31527 Tanta, Egypt, Tel.: +20 1109918 6399, E-mail: maleox68@yahoo.com, marwa.ibrahim@med.tanta.edu.eg

ISSN: 1110-0559, Vol. 42, No. 1

\section{INTRODUCTION}

Triclosan (TCS) is a chlorinated phenolic bactericide. It acts as a broad-spectrum antiseptic, disinfectant and preservative agent mainly in personal care products like hand soaps, cosmetics, detergents, toothpastes and shampoos. It is also incorporated in toys, kitchen utensils and clothes ${ }^{[1]}$. It was even suggested for the treatment of plaque and gingivitis ${ }^{[2]}$.

Widespread use of TCS makes it a serious environmental pollutant ${ }^{[3]}$ as it has been widely detected in water, sediment, biosolids, soils, aquatic species and humans ${ }^{[4]}$. TCS can be even transformed into more toxic compounds by various chemical reactions as chlorination resulting in chlorinated phenols, or biological methylation turning TCS into methyl triclosan. Nevertheless, photo oxidation of TCS results in the formation of chlorinated dibenzodioxins ${ }^{[1]}$. These serious compounds may impact the human health in various ways.

TCS is rapidly absorbed from the gastrointestinal tract, oral mucosa and human $\operatorname{skin}^{[5]}$. Acute, subacute and even chronic toxicity upon exposure to TCS were detected in many species through dermal and oral exposure ${ }^{[6]}$. TCS is metabolized in the liver and excreted by the kidney, it is readily distributed in the body and was detected in various human tissues and fluids as serum and human breast $\operatorname{milk}^{[7,8,9]}$.

Chronic exposure to TCS may lead to health hazards in many species. These effects include allergy, antibiotic resistance, skin irritations, and endocrine disruption ${ }^{[10]}$.

Many researches have documented deterioration of male reproductive health over the last few decades, resulting in increased male infertility with abnormal sperm count and 
quality. Lifestyle, nutritional and environmental factors could stand behind this deterioration ${ }^{[11]}$. One of the most important of these environmental factors is the endocrine disruptors that are seriously incriminated in reproductive toxicity. TCS potential for endocrine disruption has long concerned many researchers ${ }^{[12]}$.

The cauda epididymis is the terminal part of epididymis where the process of sperm maturation is completed; spermatozoa become motile and acquire the potential ability to fertilize oocytes. Moreover, cauda epididymis is a site for storage of mature sperms till the time of ejaculation. These sperm modifications depend on the intact healthy epididymal microenvironment provided by the absorptive and secretory properties of the epididymal lining epithelium $^{[13,14]}$. As it has been reported that TCS tend to accumulate in the epididymis of rat ${ }^{[15]}$, this has encouraged the designing of this study to make a full morphological and morphometrical evaluation of the effect of TCS and its withdrawal on the cauda epididymis of adult albino rat using different histological, immunohistochemical and biochemical techniques.

\section{MATERIAL AND METHODS}

Twenty-one adult male albino rats weighing 150-180 grams each were used in this study. They were kept in clean properly ventilated cages with free access to a balanced laboratory diet and water. The rats were kept on a $12 \mathrm{~h}$-light/12h-dark cycle before the experiment and throughout the study period. They were kept for 2 weeks before the experiment for acclimatization. The study design was approved by the Local Ethics Committee of Faculty of Medicine, Tanta University, Egypt.

\section{The animals were randomly allocated into three equal groups:}

Group I (Control group): Animals of this group were orally administered $1 \mathrm{ml}$ of distilled water daily for 8 weeks.

Group II (Triclosan-treated group): Animals were orally administered Triclosan (TCS) at a dose of $200 \mathrm{mg} /$ $\mathrm{kg}$ body weight suspended in $1 \mathrm{ml}$ of distilled water daily for 8 weeks. ${ }^{[15]}$. TCS was purchased from Sigma Aldrich Chemical Co (cat \# PHR1338, St. Louis, MO, USA).

Group III (Triclosan-withdrawal group): Animals were orally administered TCS at a dose of $200 \mathrm{mg} / \mathrm{kg}$ body weight suspended in $1 \mathrm{ml}$ of distilled water daily for 8 weeks then left for another 8 weeks without treatment.

At the end of the experiment, animals were anesthetized using intraperitoneal injection of pentobarbital $(40 \mathrm{mg} / \mathrm{kg})^{[16]}$. Blood samples were collected directly from the heart of the animals to measure the level of testosterone hormone. Serum was obtained after centrifugation and stored at $-20^{\circ} \mathrm{C}$. Laparotomy was performed and caudae epididymes were dissected out and processed for light and electron microscopy.

\section{Hormonal assay:}

The mean serum level of testosterone hormone was assayed using specific radioimmunoassay (ICN Pharmaceuticals Inc., California, USA). The values were recorded in $\mathrm{ng} / \mathrm{dl}$.

\section{For examination by light microscopy:}

Epididymal specimens were immersed in 10\% neutralbuffered formalin, washed, dehydrated, cleared and embedded in paraffin. Sections of $5 \mu \mathrm{m}$ thickness were stained with hematoxylin and eosin $(\mathrm{H} \& \mathrm{E})^{[17]}$, Periodic Acid Schiff reagent (PAS) for detection of mucopolysaccharide and Mallory's trichrome stain for detection of collagen fibers ${ }^{[18]}$.

For immunohistochemical staining for detection of androgen receptor (AR)

Sections of $5 \mu \mathrm{m}$ thickness were dewaxed, rehydrated and washed with phosphate buffered saline (PBS) and then incubated with PBS containing 10\% normal goat serum. Sections were incubated with the rabbit polyclonal antibody against androgen receptor (ab3510, Abcam, Cambridge, Massachusetts, USA) overnight in a humid chamber at $4^{\circ} \mathrm{C}$ and then incubated with biotinylated goat anti-rabbit $\operatorname{IgG}$ for $60 \mathrm{~min}$ at room temperature. Sections were incubated with a streptavidin-biotin-horseradish peroxidase complex for another $60 \mathrm{~min}$. The immunoreactivity was visualized using 3,3'-diaminobenzidine (DAB) hydrogen peroxide as a chromogen and sections were counterstained with Mayer's hematoxylin. The negative control sections were prepared by excluding the primary antibody ${ }^{[19]}$.

\section{For examination by transmission electron microscopy:}

Cauda epididymal specimens were cut into small pieces and fixed in $4 \%$ phosphate buffered glutaraldehyde (0.1 M, pH 7.3), post-fixed with $1 \%$ phosphate-buffered osmium tetroxide, then dehydrated in ascending grades of ethanol. The specimens were immersed in propylene oxide then embedded in epoxy resin mixture. Semithin sections $(1 \mu \mathrm{m}$ thick) were stained with $1 \%$ toluidine blue and examined by light microscope for proper orientation ${ }^{[20]}$. Ultrathin sections $(80-90 \mathrm{~nm})$ were stained with uranyl acetate and lead citrate, to be examined by JEOL-JEM-100 transmission electron microscope (Tokyo, Japan) at the Electron Microscopic Unit, Faculty of Medicine, Tanta University, Egypt.

\section{Morphometric analysis}

The images were obtained using a Leica microscope (DM3000, Leica, Germany) coupled to a Leica camera (DFC-290, Leica, Germany). The image analysis was done using Leica Qwin $500 \mathrm{C}$ image analyzer computer system (Leica Imaging System LTD., Cambridge, England) at Central Research Lab, Faculty of Medicine, Tanta University, Egypt. Ten different non-overlapping 
randomly-selected fields at magnification of 400 were examined for:

1. Mean epithelial height and ductal diameter of the epididymal ducts was measured in H\&E stained sections.

2. Mean relative frequency of the epididymal compartments (epithelium, lumen, and interstitium); the epithelial area was calculated as the difference between the total area of the ducts and the total luminal area, whereas the interstitium was the difference between the total area of ducts and the total field area in H\&E stained sections.

3. Mean color intensity of the positive histochemical reaction for PAS stain expressed as a magenta red coloration.

4. Mean area percentage (\%) of collagen fiber content (in Mallory's trichrome-stained sections). Total area was measured after selection by adjusting the color threshold while excluding the background and then the blue stained area was selected and measured to calculate the area percentage $(\%)=$ (blue stained area/total area) x 100 .

5. Mean color intensity of positive immunohistochemical reaction for androgen receptor (in DAB-stained sections). The color intensity was calculated by subtracting the color intensity of negative immunohistochemical control from the color intensity of positive stained specimen in serial sections.

\section{Statistical analysis}

The data were analyzed by using one-way analysis of variance (ANOVA) followed by Tukey's test for comparison between the groups using statistical package for social sciences statistical analysis software (IBM SPSS Statistics for Windows, IBM Corp, Version 22.0. Armonk, NY, USA). All values were recorded as mean \pm standard deviation. Differences were considered significant if probability value $p<0.05$ and highly significant if $p<0.001^{[21]}$

\section{RESULTS}

\section{Hormonal assay}

Serum testosterone in TCS-treated group showed a highly significant decrease $(23.62 \pm 2.89)$ compared to the control group $(41.09 \pm 3.32)$, while a non-significant difference was recorded between TCS-withdrawal group (39.89 \pm 3.45$)$ and the control group (Table 1, Histogram 1).

\section{Histological findings}

\section{Hematoxylin and eosin (H\&E) staining}

Light microscopic examination of H\&E-stained sections of cauda epididymis from control group revealed the presence of epididymal ducts containing numerous spermatozoa in the lumen. The ducts were lined with pseudostratified columnar epithelium resting on a basal lamina. The main lining cells were principal columnar cells with basally located nuclei and apical stereocilia projecting into the lumen. Clear cells with pale vacuolated cytoplasm and central nucleus were observed inbetween the principal cells, while basal cells rested on the basal lamina among the bases of principal cells. Few halo cells (intraepithelial lymphocyte) were detected at different levels of the epithelium from the basal lamina to the lumen. They were small rounded cells with a scanty pale cytoplasm. The epididymal duct was surrounded by a thin layer of smooth muscle fibers and connective tissue (Fig. 1).

Sections from TCS-treated group II revealed that the epididymal ducts contained apparently few spermatozoa in the lumen. Principal cells lining the epididymal duct showed vacuoles compressing their nuclei with some pyknotic nuclei and sparse stereocilia. Many halo cells were observed in close contact with the tubular lumen. Many basal cells were observed inbetween the principal cells. Epithelial lining showed focal areas of stratification in addition to some areas of discontinuity. Moreover, the smooth muscle layer surrounding the epididymal duct showed focal thickening and sometimes separation from the bases of the ducts. Widened interstitium inbetween the ducts with cellular infiltrations and some congested blood vessels were observed (Figs. 2, 3).

Sections from TCS-withdrawal group III depicted minimal structural changes in epididymal ducts with scanty stereocilia. Few vacuolated cells were observed. Numerous spermatozoa could be seen in the epididymal lumen (Fig. 4).

Morphometric analysis revealed a significant decrease in both epithelial height and ductal diameter $(15.8 \pm 2.39$, $136.12 \pm 16.89$ respectively) in group II compared to the control $(22.40 \pm 3.53,155.89 \pm 12.44$ respectively). While a non-significant difference in both parameters was observed between group III (19.76 $\pm 3.71,148.11 \pm 9.89$ respectively) and the control group. Relative frequency (\%) of different epididymal compartments (ductal epithelium, ductal lumen and interstitium) showed a significant decline in both ductal epithelium and ductal lumen percentages in group II (17.52 $\pm 3.31,53.22 \pm 6.45$ respectively) compared to the control $(23.43 \pm 3.03,66.65 \pm 4.90$ respectively), while showed a significant increase in interstitium percentage in group II (19.26 \pm 4.09$)$ compared to the control $(9.92 \pm 1.87)$. On the other hand, a non-significant difference in all parameters was observed between group III $(21.33 \pm 2.54$, $62.88 \pm 5.13,12.34 \pm 3.71$ respectively) and the control group (Table 1) (Histogram 1).

\section{Mallory's trichrome staining}

Mallory's trichrome-stained sections from control group showed few blue-stained collagen fibers in the connective tissue surrounding epididymal ducts (Fig. 5). While section from TCS-treated group revealed prominent blue-stained collagen fibers surrounding the epididymal ducts and blood vessels (Fig. 6). On the other hand, 
sections from group III depicted few collagen fibers in the connective tissue surrounding epididymal ducts (Fig. 7).

Morphometric analysis of the mean area percentage of the collagen fiber content revealed a highly significant increase in the TCS-treated group (17.38 \pm 3.09$)$ compared to the control group $(8.72 \pm 1.55)$, while a non-significant difference was observed between group III (10.11 \pm 1.99$)$ and the control group (Table 1) (Histogram 1).

\section{Periodic Acid Schiff (PAS) staining}

PAS-stained sections from control group showed a strong characteristic magenta red PAS reaction in the basal laminae of the epididymal ducts associated with intact thin apical PAS reaction in the lining epithelial cells (Fig. 8), whereas section from TCS-treated group revealed an enhanced PAS reaction in the apparently thickened basal lamina, while a diminished PAS reaction in the apical parts of the lining epithelial cells was observed (Fig. 9). On the other hand, sections from group III depicted a strong PAS reaction in the basal laminae of the epididymal ducts with intact thin apical PAS reaction in the lining epithelial cells (Fig. 10).

Morphometric analysis of the mean color intensity of PAS stain in the TCS-treated group revealed significant increase $(6.01 \pm 1.46)$ compared to the control group (15.37 \pm 2.88$)$, while a non-significant difference was observed between group III (13.57 \pm 1.49$)$ and the control group (Table 1) (Histogram 1).

\section{Androgen receptor (AR) immunohistochemical staining}

AR-immunostained sections from control group showed a strong exclusively nuclear immunoreaction in the epithelial lining of the epididymal ducts in the form of brown coloration (Fig. 11). While sections from TCS-treated group showed an apparently weak nuclear immunoreaction in the epithelial lining of the epididymal ducts, in addition to some focal cytoplasmic positive immunoreaction (Fig.12). On the other hand, sections from group III revealed a strong nuclear androgen receptor immunoreaction in the epithelial cells lining the epididymal ducts (Fig. 13).

Morphometric analysis of the mean color intensity of AR immunostaining in the TCS-treated group revealed a highly significant decrease $(38.71 \pm 4.88)$ compared to the control group $(60.50 \pm 5.07)$, while a non-significant difference was observed between group III (56.93 \pm 6.11$)$ and the control group (Table 1, Histogram 1).

\section{Transmission electron microscopy}

Examination of ultrathin sections from the control group showed the characteristic ultrastructure of cauda epididymis epithelial lining; Principal cells with basal euchromatic nuclei showed apical stereocilia projecting into the lumen. Clear cells contained numerous clear vacuoles and lipid droplets (Fig. 14). Halo cells were observed among the principal cells. They showed pale cytoplasm and central rounded or oval slightly indented euchromatic nuclei. The basal cells were small rounded or oval in shape with large euchromatic nuclei and scanty cytoplasm. These epithelial cells overlied a regular basement membrane (Fig. 15).

Examination of ultrathin sections of cauda epididymis from TCS-treated group revealed principal cells with irregular apical cytoplasmic projections, sparse to few stereocilia as well as cellular blebbing into the lumen. Principal cells showed irregular nuclei and vacuolated cytoplasm with many lysosomes, dilated proliferated Golgi apparatus and rough endoplasmic reticulum (Figs. 16, 17). Clear cells showed some cytoplasmic projections, large apical vacuoles and few lipid droplets (Fig. 18). Migrating halo cells with vacuolated cytoplasm widely separated from the surrounding principal cells were observed. Abundant collagen fibers were detected underneath the epididymal tubular epithelial cells (Fig. 19).

Examination of ultrathin sections of cauda epididymis from TCS-withdrawal group depicted minimal structural changes in cauda epididymis epithelial lining, where some principal cells showed few vacuoles (Fig. 20)

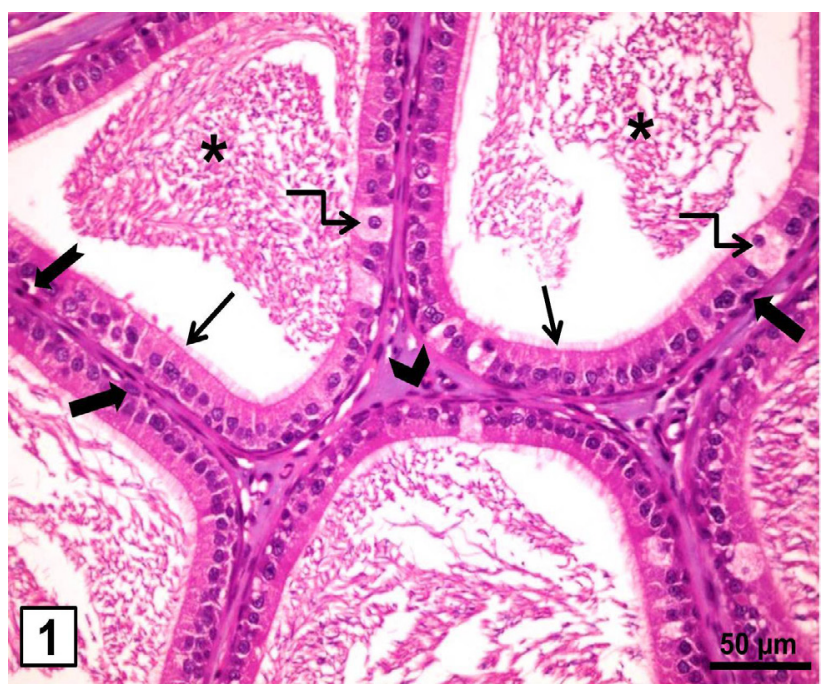

Fig. 1: A photomicrograph of a section of the cauda epididymis from control group showing epididymal ducts lined with principal columnar cells with basal nuclei and stereocilia (thin arrows), clear cells with pale vacuolated cytoplasm (angular arrows), basal cells resting on the basal lamina (thick arrows), and halo cells with scanty pale cytoplasm (notched arrow). Thin layer of smooth muscle fibers surrounds each epididymal duct (arrow head). Notice numerous spermatozoa in the epididymal lumen (asterisks). (H\&E X400, scale bar $=50 \mu \mathrm{m})$ 


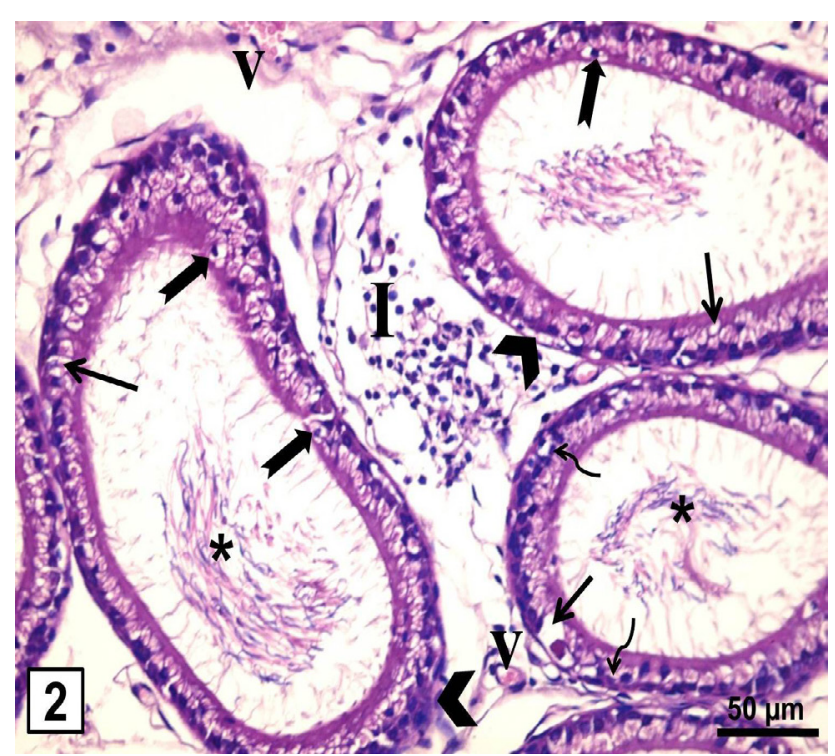

Fig. 2: A photomicrograph of a section of the cauda epididymis from TCS-treated group showing principal cells with vacoules compressing their nuclei (thin arrows), pyknotic nuclei (wavy arrows) and sparse stereocilia. Many halo cells (notched arrows) are seen adluminal. Smooth muscle layer (arrow heads) is thickened or separated from the base of the epididymal ducts. Mononuclear cellular infiltration (I) is observed in the widened interstitium. Some congested blood vessels are observed as well (v). Notice reduced sperm density in the lumen of ducts (asterisks). (H\&E $\mathrm{X} 400$, scale bar $=50 \mu \mathrm{m}$ )

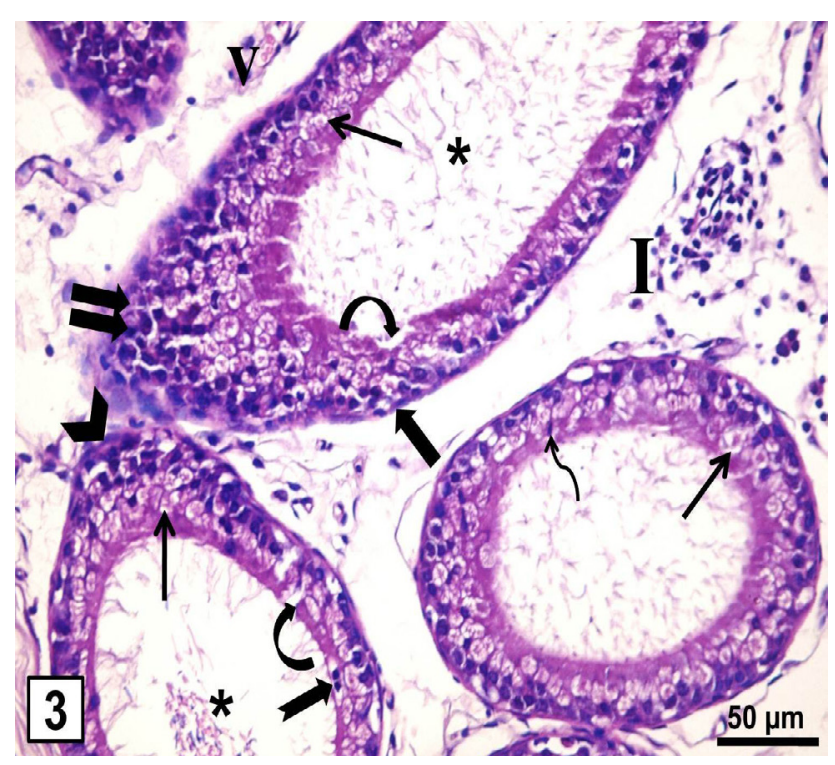

Fig. 3: A photomicrograph of a section of the cauda epididymis from TCStreated group showing principal cells with vacoules compressing their nuclei (thin arrows), pyknotic nuclei (wavy arrows) and sparse stereocilia. Many halo cells (notched arrows) are seen adluminal. Multiple basal cells are observed (thick arrows). Smooth muscle layer (arrow heads) shows focal thickening. Mononuclear cellular infiltration (I) is observed in the widened interstitium. Some congested blood vessels are observed as well (v). Focal discontinuity is seen inbetween the epithelial lining (curved arrows). Focal stratification can be detected (double arrows). Notice reduced sperm density in the lumen of ducts (asterisks). (H\&E X400, scale bar $=50 \mu \mathrm{m})$

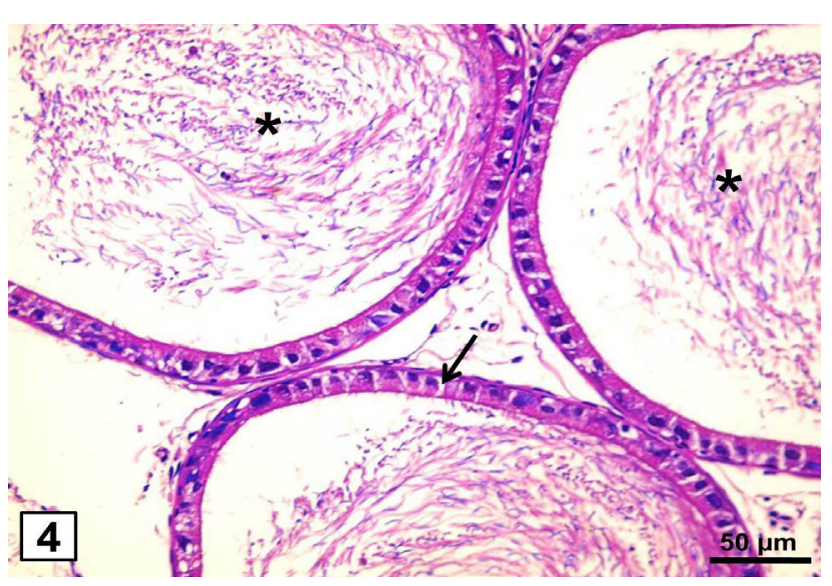

Fig. 4: A photomicrograph of a section of the cauda epididymis from TCS-withdrawal group showing minimal changes in epididymal ducts with scanty stereocilia. Numerous spermatozoa are seen in the epididymal lumen (asterisks). Notice few vacuolated cells (thin arrow). (H\&E X400, scale bar $=50 \mu \mathrm{m})$

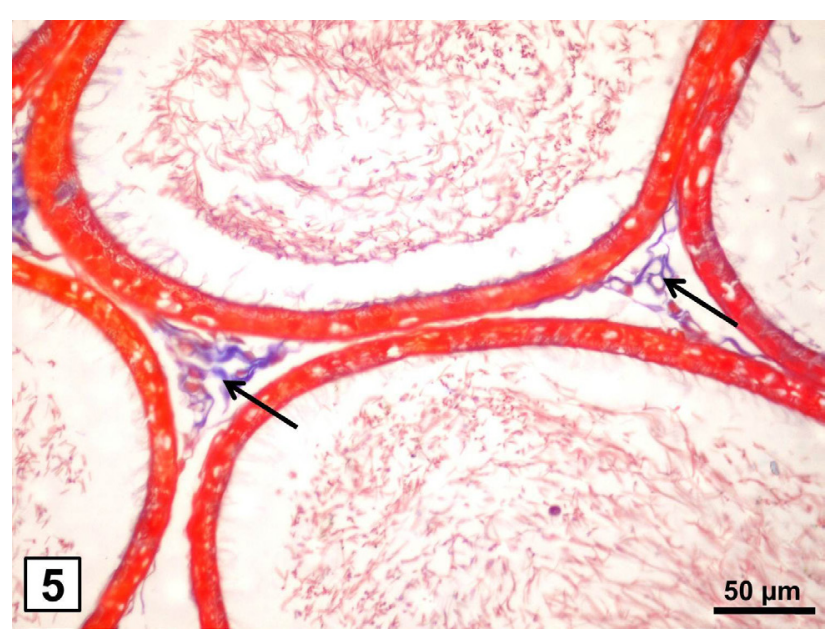

Fig. 5: A photomicrograph of a section of the cauda epididymis from control group showing thin blue-stained collagen fibers in the connective tissue surrounding epididymal ducts (thin arrows). (Mallory's trichrome stain $\mathrm{X} 400$, scale bar $=50 \mu \mathrm{m})$

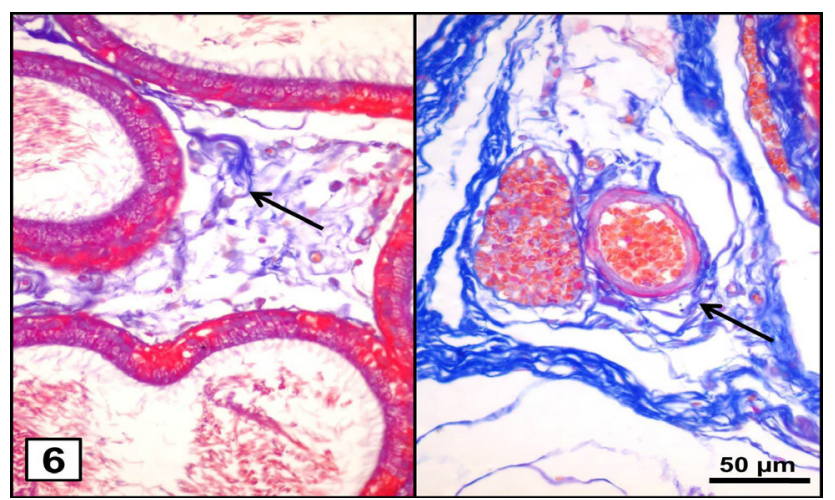

Fig. 6: A photomicrograph of a section of the cauda epididymis from TCS-treated group showing prominent blue-stained collagen fibers surrounding the epididymal ducts and blood vessels (thin arrows). (Mallory's trichrome stain X400, scale bar $=50 \mu \mathrm{m}$ ) 


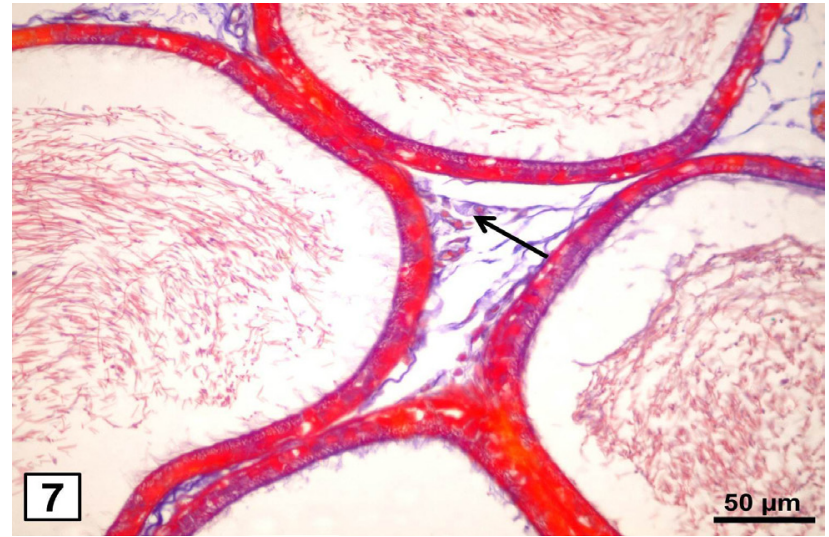

Fig. 7: A photomicrograph of a section of the cauda epididymis from TCS-withdrawal group showing few blue-stained collagen fibers surrounding the epididymal ducts (thin arrow). (Mallory's trichrome stain $\mathrm{X} 400$, scale bar $=50 \mu \mathrm{m}$ )

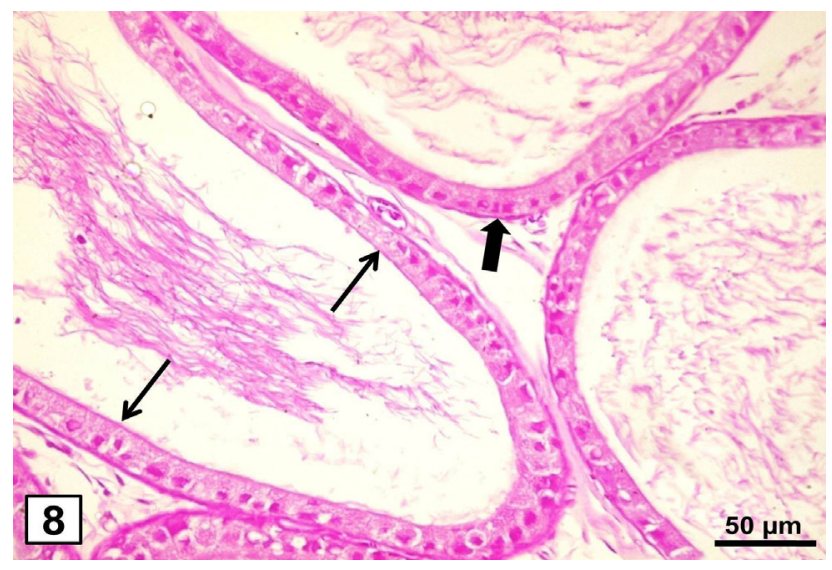

Fig. 8: A photomicrograph of a section of the cauda epididymis from control group showing a strong PAS reaction in the basal laminae of the epididymal ducts (thick arrows) with intact thin apical PAS reaction in the lining epithelial cells (thin arrows) . (PAS stain X400, scale bar $=50 \mu \mathrm{m}$ )

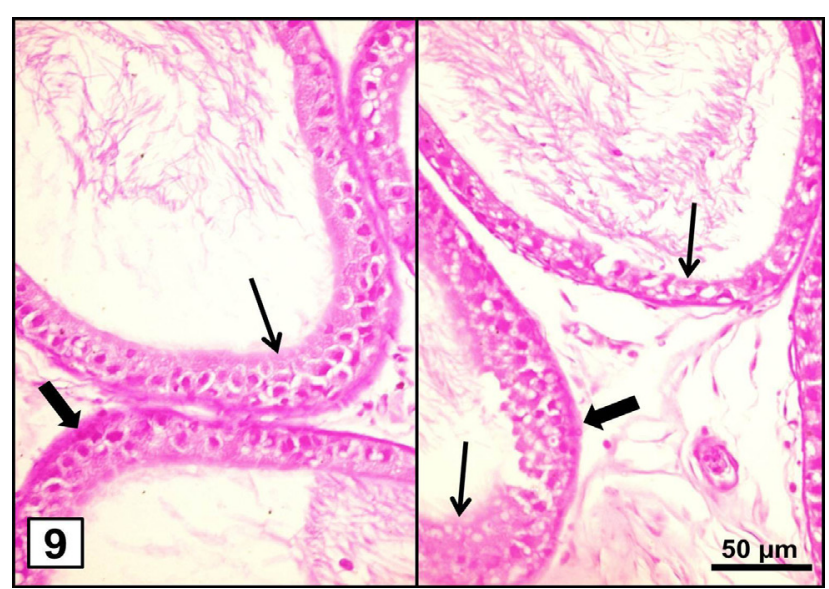

Fig. 9: Photomicrographs of sections in the cauda epididymis from TCS-treated group showing an enhanced PAS reaction in the apparently thickened basal lamina (thick arrows). Notice diminished PAS reaction in the apical parts of the lining epithelial cells (thin arrows). (PAS stain $\mathrm{X} 400$, scale bar $=50 \mu \mathrm{m}$ )

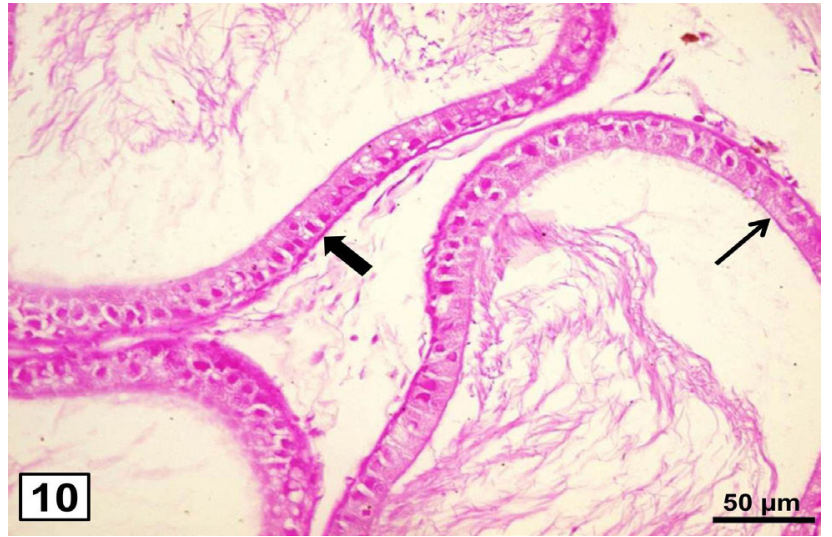

Fig. 10: A photomicrograph of a section of the cauda epididymis from TCS-withdrawal group showing a strong PAS reaction in the basal laminae of the epididymal ducts (thick arrow) with intact thin apical PAS reaction in the lining epithelial cells (thin arrow). (PAS stain X400, scale bar $=50 \mu \mathrm{m})$

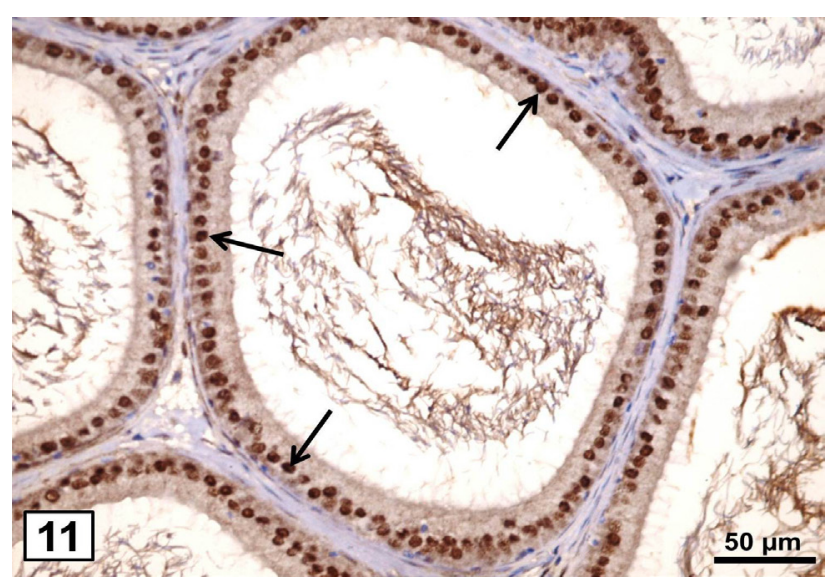

Fig. 11: A photomicrograph of a section of the cauda epididymis from control group showing a strong exclusively nuclear androgen receptor (AR) immunoreaction in the epithelial cells lining the epididymal ducts (thin arrows). (AR immunostaining X400, scale bar=50 $\mathrm{m}$ )

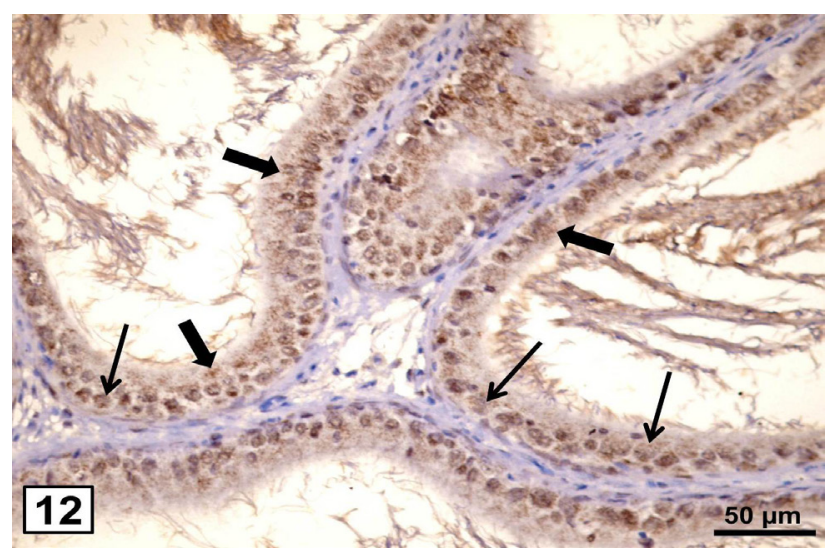

Fig. 12: A photomicrograph of a section of the cauda epididymis from TCS-treated group (showing a weak nuclear androgen receptor immunoreaction in the epithelial cells lining the epididymal ducts (thin arrows). Notice some focal cytoplasmic reaction (thick arrows). (AR immunostaining X400, scale bar $=50 \mu \mathrm{m}$ ) 


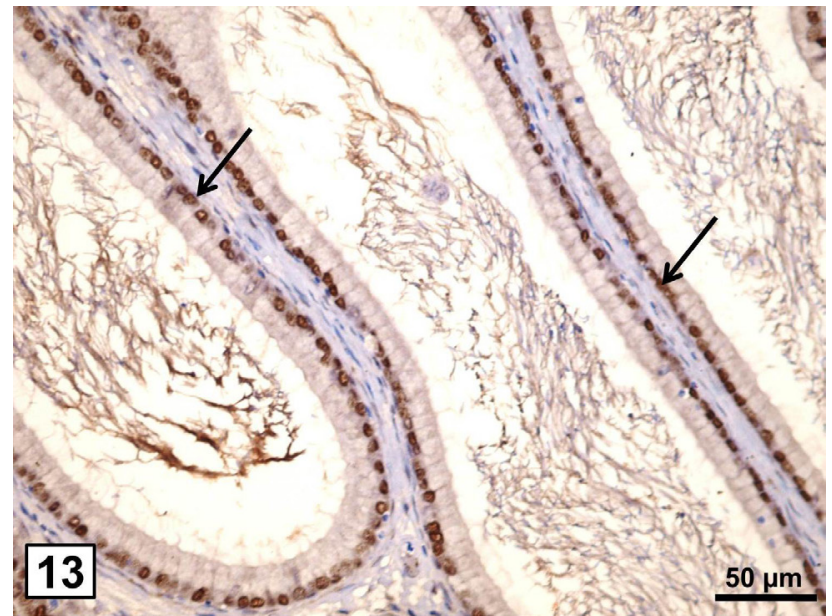

Fig. 13: A photomicrograph of a section of the cauda epididymis from TCS-withdrawal group showing a strong nuclear androgen receptor (AR) immunoreaction in the epithelial cells lining the epididymal ducts (thin arrows). (AR immunostaining X400, scale bar $=50 \mu \mathrm{m}$ )

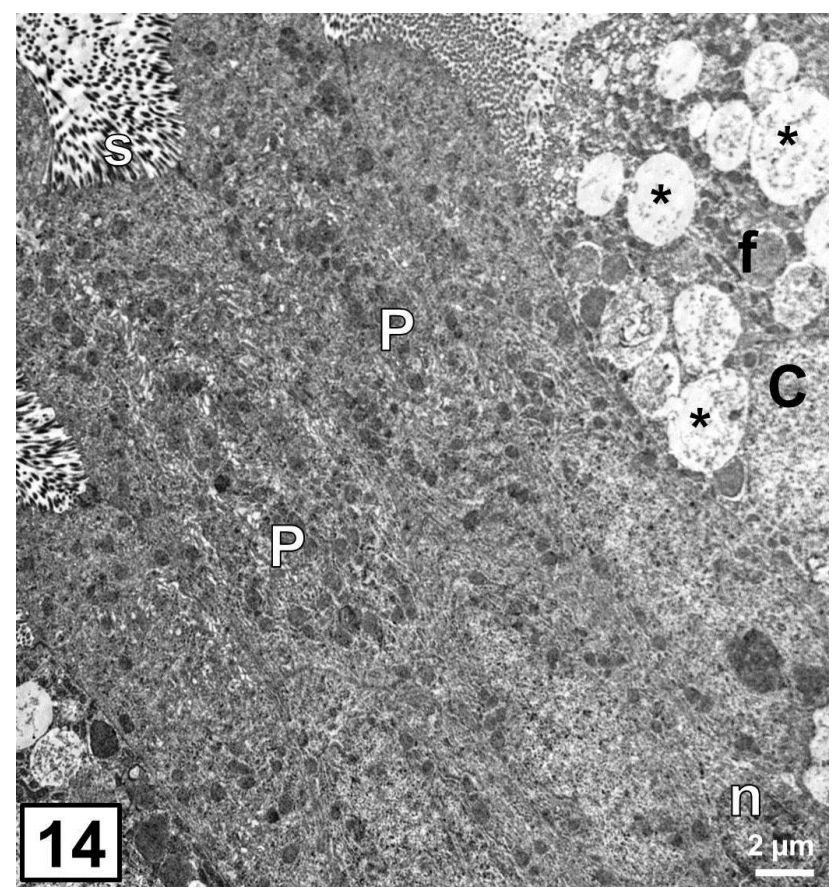

Fig. 14: An electron micrograph of the cauda epididymis from control group showing principal cells (P) with basal euchromatic nucleus (n) and stereocilia (s) projecting into the lumen. Clear cell (C) with numerous vacuoles (asterisks) and lipid droplets (f) is observed. (TEM X5850, scale bar $=2 \mu \mathrm{m})$

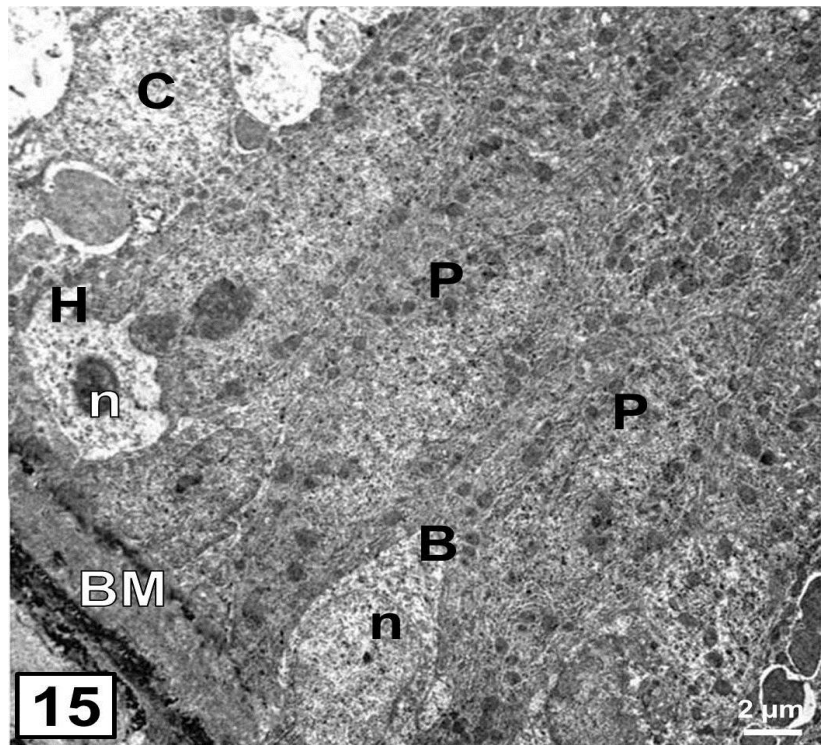

Fig. 15: An electron micrograph of the cauda epididymis from control group showing halo cell $(\mathrm{H})$ with central oval nucleus $(\mathrm{n})$ and pale cytoplasm inbetween the principal cells (P). Basal cell (B) with large euchromatic nucleus (n) and scanty cytoplasm resting on a regular basement membrane (BM) is observed. Notice clear cell (C). (TEM X5850, scale bar $=2 \mu \mathrm{m})$

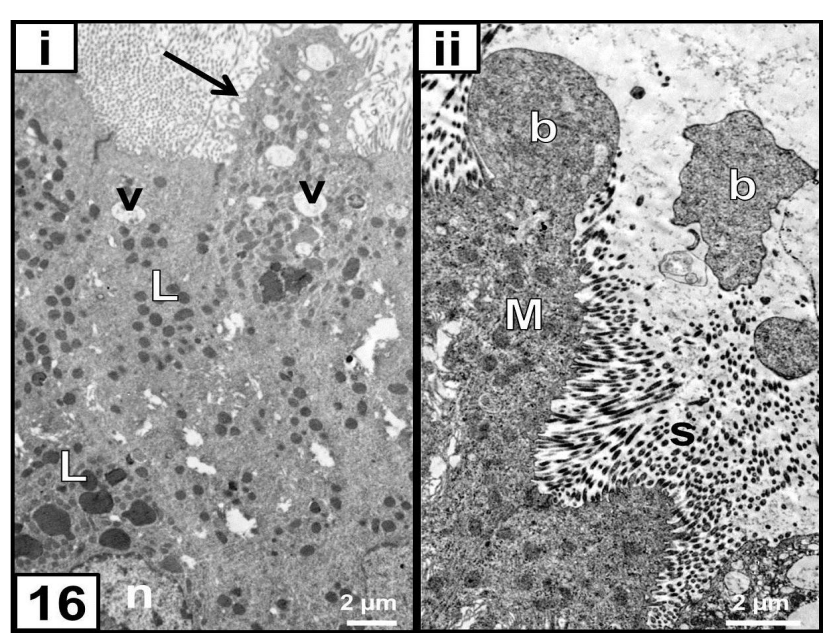

Fig. 16: An electron micrograph of the cauda epididymis from TCStreated group showing principal cells with irregular apical cytoplasmic projections (arrow), few stereocilia (s) and cellular blebbing (b) into the lumen. Notice presence of irregular nucleus (n), vacuoles (v), mitochondria (M) and many lysosomes (L) in the cytoplasm. (TEM, i, ii $\mathrm{X} 5850,8780$ respectively, scale bar $=2 \mu \mathrm{m}$ ) 


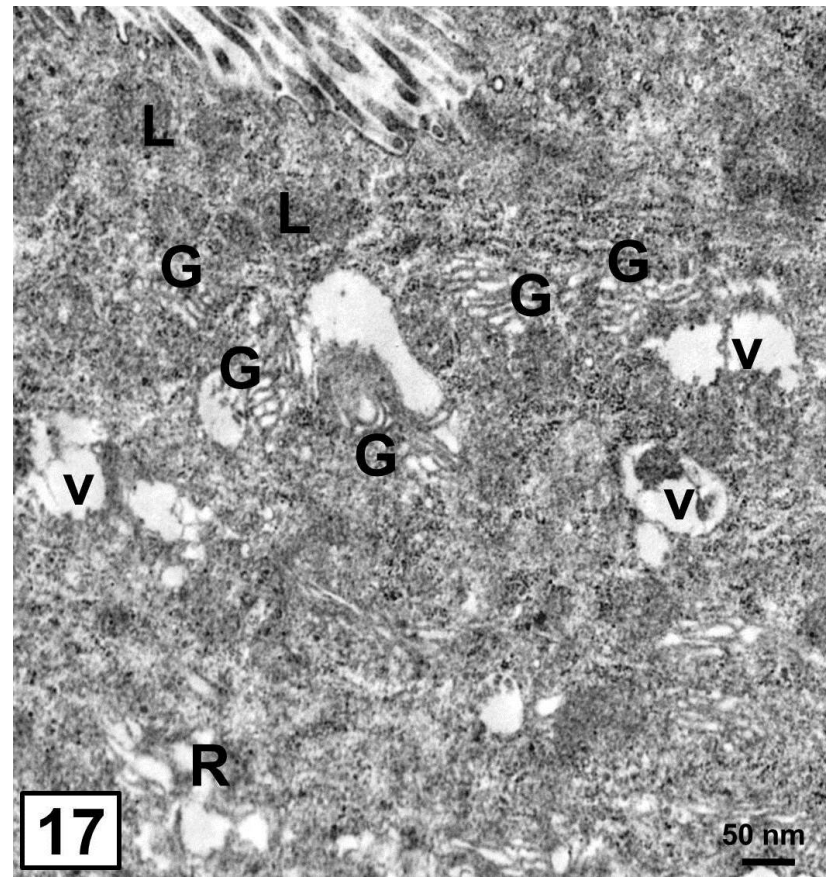

Fig. 17: An electron micrograph of the cauda epididymis from TCStreated group showing dilated proliferated Golgi apparatus $(G)$ and rough endoplasmic reticulum $(\mathrm{R})$ in principal cell. Notice presence of lysosomes (L) and multiple vacuoles (v). (TEMX23400, scale bar=50 nm)

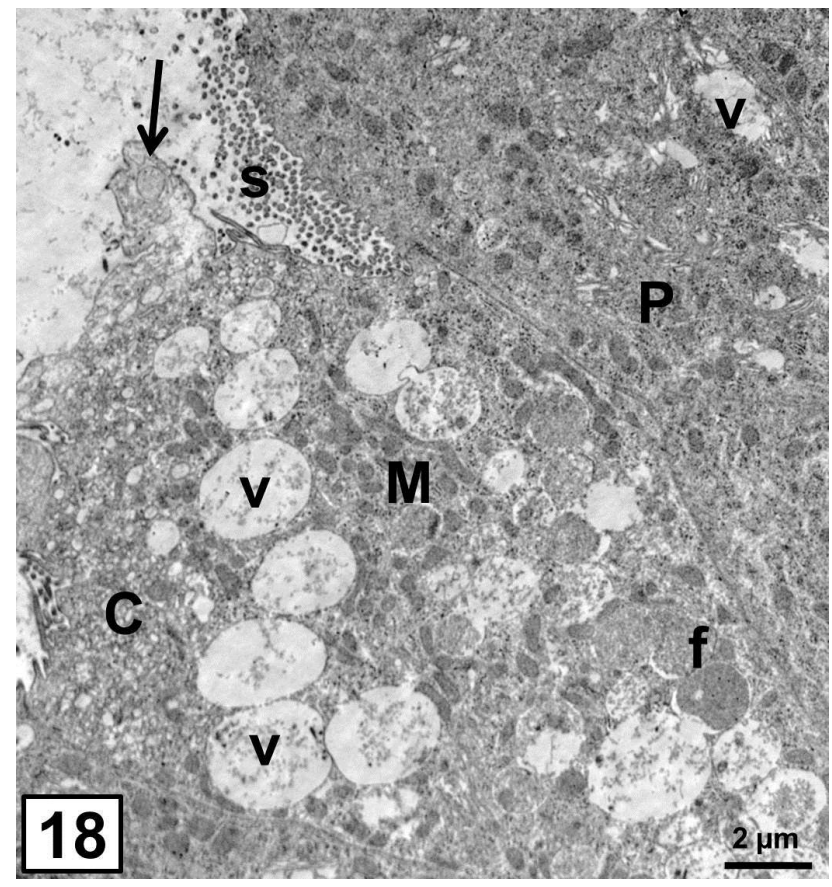

Fig. 18: An electron micrograph of the cauda epididymis from TCStreated group showing a clear cell (C) with cytoplasmic projections (arrow), large apical vacuoles (v) and few lipid droplets (f). Notice principal cell $(\mathrm{P})$ with sparse stereocila $(\mathrm{s})$ and vacuolated cytoplasm (v). (TEMx8780, scale bar $=2 \mu \mathrm{m}$ )

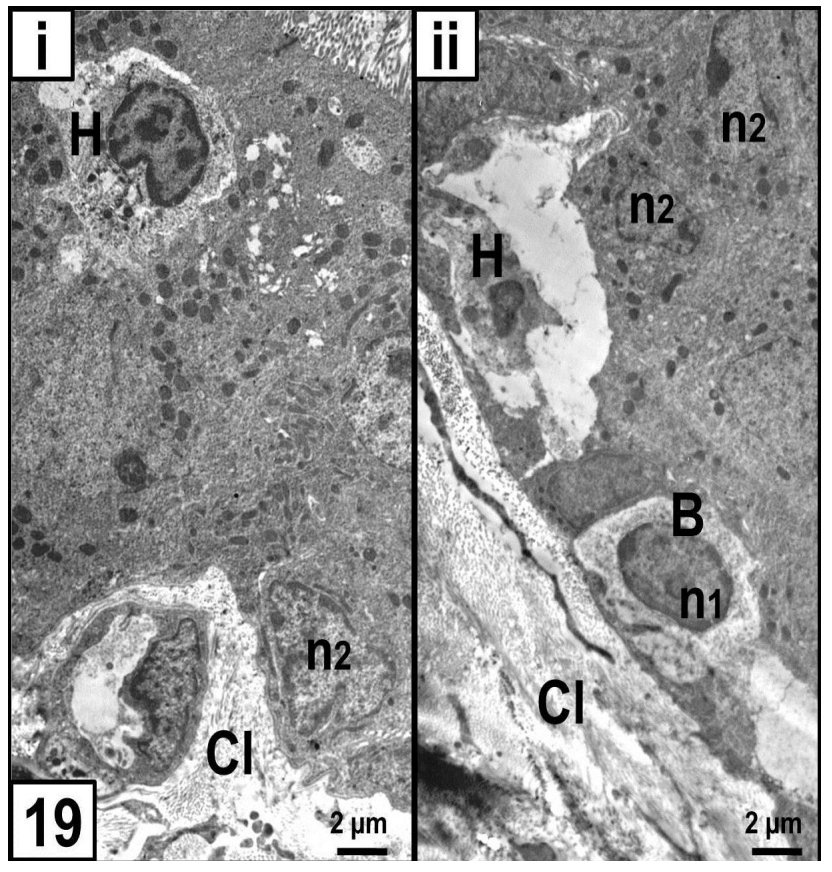

Fig. 19: An electron micrograph of the cauda epididymis from TCStreated group showing migrating halo cell $(\mathrm{H})$ with vacuolated cytoplasm and basal cell (B) with dark nucleus (n1). Abundant collagen fibers (Cl) are observed underneath the epididymal tubular epithelial cells. Notice indented nuclei of principal cells (n2). (TEM, i, ii X5850, scale bar=2 $\mu \mathrm{m}$ )

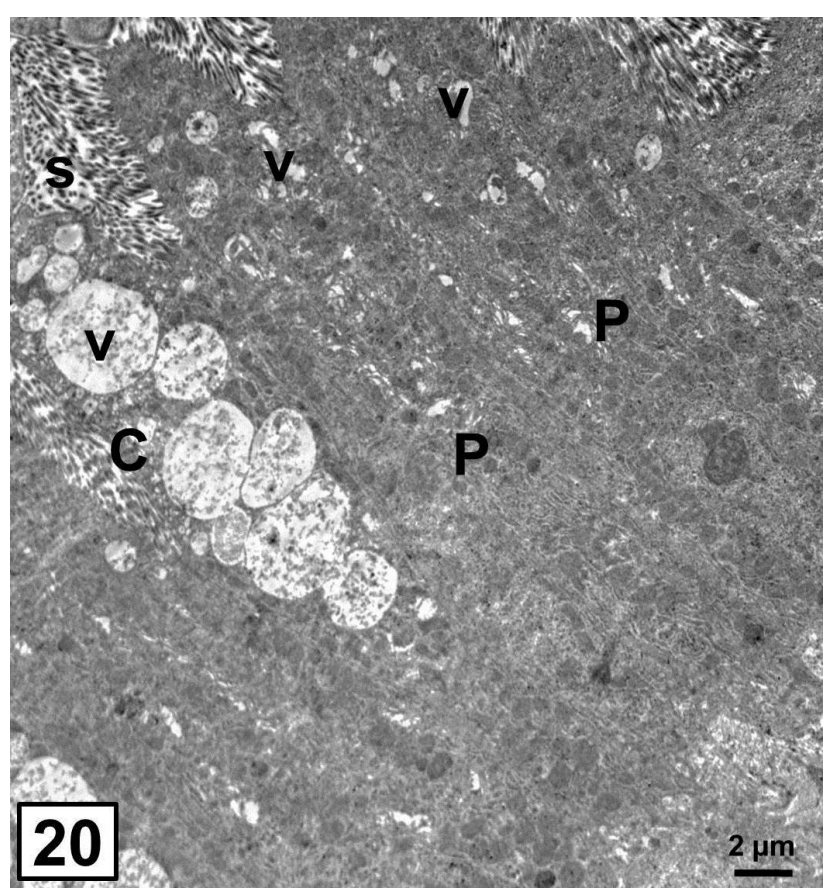

Fig. 20: An electron micrograph of the cauda epididymis from TCSwithdrawal group showing principal cells (P) with vacuoles (V) and stereocilia (s) projecting into the lumen. Notice clear cell (C) with numerous vacuoles (v) is observed. (TEM X5850, scale bar=2 $\mu \mathrm{m}$ ) 
Table 1: Morphometric and statistical analysis of cauda epididymis different parameters:

\begin{tabular}{|c|c|c|c|}
\hline Parameters & Group I & Group II & Group III \\
\hline \multicolumn{4}{|l|}{ Hormonal assay } \\
\hline Serum testosterone (ng/dl) & $41.09 \pm 3.32$ & $23.62 \pm 2.89^{* *}$ & $39.89 \pm 3.45$ \\
\hline \multicolumn{4}{|l|}{ Morphometric parameters } \\
\hline Epithelial height $(\mu \mathrm{m})$ & $22.40 \pm 3.53$ & $15.8 \pm 2.39^{*}$ & $19.76 \pm 3.71$ \\
\hline Ductal diameter $(\mu \mathrm{m})$ & $155.89 \pm 12.44$ & $136.12 \pm 16.89^{*}$ & $148.11 \pm 9.89$ \\
\hline \multicolumn{4}{|c|}{ Mean relative frequency (\%) of epididymal compartments: } \\
\hline Ductal epithelium (\%) & $23.43 \pm 3.03$ & $17.52 \pm 3.31^{*}$ & $21.33 \pm 2.54$ \\
\hline Ductal lumen $(\%)$ & $66.65 \pm 4.90$ & $53.22 \pm 6.45^{*}$ & $62.88 \pm 5.13$ \\
\hline Interstitium (\%) & $9.92 \pm 1.87$ & $19.26 \pm 4.09^{*}$ & $12.34 \pm 3.71$ \\
\hline \multicolumn{4}{|l|}{ Special staining } \\
\hline Mean area $\%$ of collagen content & $8.72 \pm 1.55$ & $17.38 \pm 3.09^{* *}$ & $10.11 \pm 1.99$ \\
\hline Mean color intensity of PAS stain & $15.37 \pm 2.88$ & $6.01 \pm 1.46^{*}$ & $13.57 \pm 1.49$ \\
\hline \multicolumn{4}{|l|}{ Immunohistchemical staining } \\
\hline Mean color intensity of AR reaction & $60.50 \pm 5.07$ & $38.71 \pm 4.88^{* *}$ & $56.93 \pm 6.11$ \\
\hline
\end{tabular}

Data is expressed as mean \pm standard deviation. * indicates significant, ** indicates highly significant vs control.

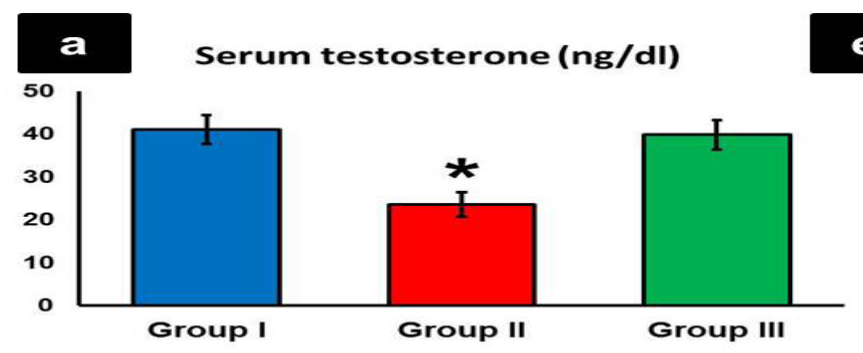

Relative frequency (\%) of epididymal
compartments

(\%)
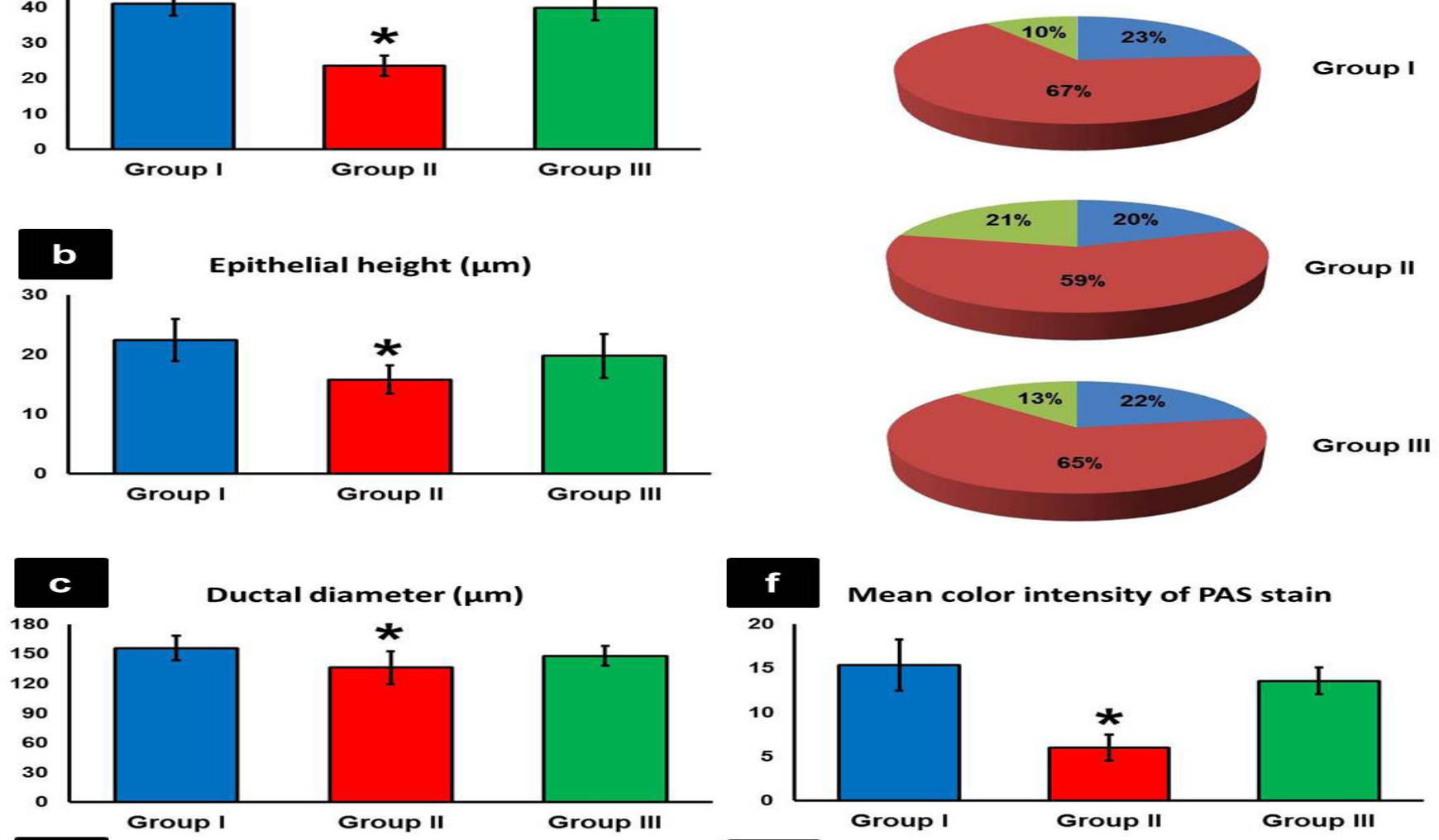

d Mean area \% of collagen content

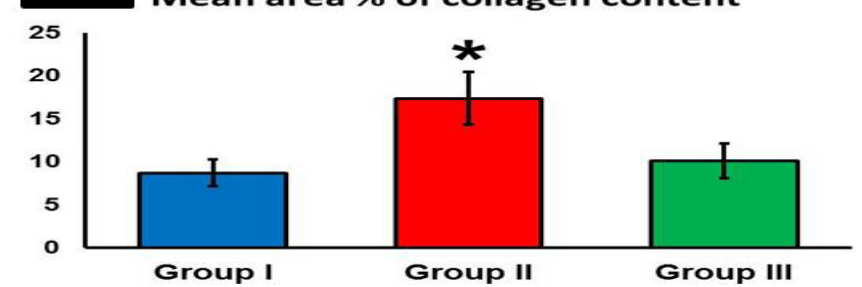

g Mean color intensity of AR reaction

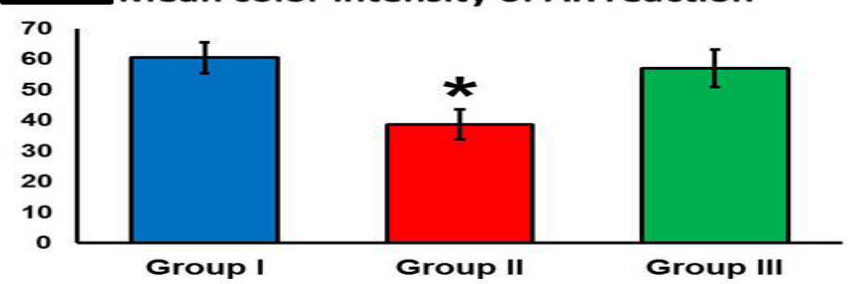

Histogram 1: a) Serum testosterone (ng/dl), b) Epithelial height ( $\mu \mathrm{m})$, c) Ductal diameter $(\mu \mathrm{m})$, d) Mean area \% of collagen content, e) Mean relative frequency $(\%)$ of epididymal compartments, f) Mean color intensity of PAS stain, g) Mean color intensity of AR reaction, * indicates significance vs control. 


\section{DISCUSSION}

Human exposure to chemicals is becoming more and more inevitable. Most of these chemicals are hormonally active compounds that causes endocrinal disturbance and affect different system in the body especially the reproductive system ${ }^{[22]}$. Although it is highly detected across the ecosystem, the health hazards of TCS have not been yet fully studied. TCS is currently suspected to be a potential male reproductive toxicant ${ }^{[23]}$.

In the current work, the effect of TCS on the adult rat was studied, where the results showed many changes at the level of structure and function of the reproductive system namely serum testosterone, androgen receptor and structure of the epididymis. In relation to serum testosterone, TCStreated group showed a highly significant decrease in testosterone level compared to the control group as was similarly reported in other studies ${ }^{[24]}$, where the effect of TCS on puberty and thyroid hormones in male Wistar rats was investigated and they found that TCS decreased the serum testosterone level. This was explained by the effect of TCS in decreasing synthesis of androgens which could be mediated through the downregulation of various signal molecules, as mRNA for testicular steroidogenic acute regulatory (StAR) protein, cytochrome P450scc, cytochrome P450C17, 3 $\beta$-hydroxysteroid dehydrogenase

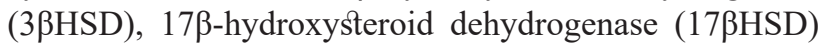
and $\mathrm{AR}^{[25]}$. Moreover, TCS reduced the activity of adenyl cyclase enzyme leading to decreased synthesis of cAMP, which then disturbed the function of major steroidogenic enzymes leading to reduced testosterone production in Leydig cells ${ }^{[24]}$ or acted as an antagonist of its effect on androgen receptors ${ }^{[26]}$.

The present results of AR immunohistochemical staining in the TCS-treated group revealed highly significant decrease in the mean color intensity of AR immunostaining compared to the control group. This finding could be a result of the direct interaction of TCS with the cells where it acts as antiandrogen ${ }^{[27]}$. Moreover, it was documented that TCS has an anti-androgenic activity in human breast cancer cells through binding to androgen receptors ${ }^{[28]}$. Other mechanism of antiadrogenic effect of TCS is through increasing the effect of estrodial and coactivation of estrogen receptors (ERs) ${ }^{[29,30]}$, where some authors reported the significant expression of ERs in the epididymis ${ }^{[31]}$. Nevertheless, other researchers stated that TCS has the affinity for binding with both androgen and estrogen receptors in vitro $^{[32]}$. A peculiar cytoplasmic expression of AR could be reported in the current work, Nguyen et al. ${ }^{[33]}$ attributed the cytoplasmic expression of AR to the absence of its ligand, i.e. androgens, which could be explained in the present work by the reported extreme drop in serum testosterone in TCS-treated group.

During the course of this study, few spermatozoa could be detected in the lumen. This observation was similarly reported in some previous studies, where TCS was found to affect the sperm concentration, sperm count, number of moving sperms, and number of normal morphologic sperms ${ }^{[15]}$. Another study documented that high dose of TCS decreased the sperm density as well as decreased the number of sperm produced per day in prepubertal rats exposed to TCS, which could be attributed to the effect of TCS on the level of testosterone and other hormones like FSH and LH, as well as inhibiting androgen receptor protein expression. These hormones are essential for the process of spermatogenesis, which finally resulted in inhibition of spermatogenesis and decreased number of sperms with bad quality of semen ${ }^{[10]}$. Additionally, Riad et $a{ }^{[34]}$ reported that TCS has significantly decreased the number and motility of sperm in weanling male rats as well as significantly decreased the testosterone level. They attributed this finding to the induction of testicular oxidative stress by TCS.

As regard the morphological changes, the current work revealed vacuoles compressing the nuclei of principal cells of the epididymal lining with some pyknotic nuclei and sparse stereocilia. Moreover, many halo cells were observed in close contact with the tubular lumen. Epithelial lining showed focal areas of stratification in addition to some areas of discontinuity. Significant decrease in both epithelial height and ductal diameter were observed. These results come in consistence with other studies reporting that chemical compounds similar to TCS cause detachment of stereocilia and vacuolation of the epididymal lining. They argued that these degenerative changes were due to disturbance in the levels of ARs and ERs, which play important rule in the functioning of epididymis ${ }^{[35,36]}$.

Similarly, Lan et al..$^{[15]}$ observed a TCS-induced damage in the cauda epididymis in the form of exfoliated vacuolated epithelial cells and detached stereocilia. They reported by using special kinetic parameters that TCS has a faster-level elimination rate in the testes and prostates compared to those in the plasma, while it has a tendency to accumulate in the epididymis. They attributed the variation in TCS distribution in different reproductive organs to the different tissue structures of these organs. They concluded that the most affected cells were the lining epithelium of the epididymis.

In the present work, it could be demonstrated that the smooth muscle layer surrounding the epididymal duct depicted focal thickening and sometimes separation from the bases of the ducts. A study conducted on the effect of TCS on the vascular function of rat arteries documented that TCS induced a vasorelaxation effect on the smooth muscle of the artery. They attributed their finding to the changes in the mitochondrial membrane potential leading to an increase in cytoplasmic level of $\mathrm{Ca}+$ and production of reactive oxygen species (ROS), thus resulting in activation and proliferation of smooth muscle cells ${ }^{[37]}$.

Signs of inflammation and fibrosis were recorded in the current work in the form of widened interstitium in between the ducts with cellular infiltrations and some congested blood vessels. Excessive collagen fibers surrounding 
the epididymal ducts and blood vessels were detected by Mallory's trichrome stain and confirmed by EM. Similarly, stromal hypercellularity, epithelial dysplasia and inflammation were reported in the testis and epididymis of transgenic ( $\mathrm{Tg}$ ) mice expressing human fibroblast growth factor $8 \mathrm{~b}$. They explained their findings by the effect of fibroblast growth factor on the stromal cells ${ }^{[38]}$. Moreover, excessive collagen deposition and fibrosis were documented upon the study of the effect of TCS on rat liver. The researchers reported that TCS induced hepatocyte proliferation and fibrogenesis which could be explained by the production of ROS and inflammatory cell aggregation. TCS induced activation of the NADPH oxidase, expression of inflammatory cytokines, such as CXCR2 and TNF $\alpha$ and elevated the level of $\alpha$ - smooth muscle actin $(\alpha-\text { SMA })^{[39]}$.

Moreover, a decreased PAS reaction in the apical parts of the epidydimal epithelial cells could be observed in the current work, which might be due to loss of pseudostratified epithelium lining the epididymis ${ }^{[40]}$.

Ultrastructural findings from the present work showed irregular apical cytoplasmic projections, sparse stereocilia and shedding of epithelial remnants into the lumen. The principal cells showed irregular nuclei and vacuolated cytoplasm with many lysosomes and extremely dilated Golgi apparatus and rough endoplasmic reticulum. The clear cells depicted some cytoplasmic projections, large apical vacuoles. Migrating halo cells with vacuolated cytoplasm widely separated from the surrounding principal cells were observed. Similar findings were reported in the seminiferous tubules of rats treated with TCS, where Sertoli cells appeared with vacuolated cytoplasm, degenerated mitochondria and increased lysosomal activity, together with decreased height of the spermatogenic epithelium. These findings were most probably related to the effect of decreased testosterone hormone which is the key factor in stabilizing and maintaining the structure and function of male reproductive system ${ }^{[41]}$. In the same hand, some authors reported that flutamide (an antiandrogen) administration lead to atrophy of the lining epithelium of the epidydimis, which could have been a result of the decreased height of the lining epithelium due to the loss of pseudostratified epithelium and its replacement with flat cells ${ }^{[42]}$. These data come in favor of confirming the antiandrogenic effect of TCS.

Additionally, electron microscopic examination of the current study revealed increased lysosomes, dilated proliferated Golgi apparatus and rough endoplasmic reticulum. Similar results were observed during studying the effect of bisphenol A on the epididymis of adult rats ${ }^{[43]}$. These changes might be due to alterations in the secretory function of the cells induced by TCS. Moreover, the clear cells showed some cytoplasmic projections, large apical vacuoles and few lipid droplets. Some authors have attributed these changes in the clear cells to the increased exfoliated cells and dead sperms in the lumen, thus inducing an increased endocytotic activity of the clear cells, where it was established that the main function of clear cells is endocytosis of different particles from the lumen of the epididymis such as necrotic particles remnant of sperms and some proteins ${ }^{[44]}$.

Moreover, migrating halo cells with vacuolated cytoplasm widely separated from the surrounding principal cells were observed. This could be a result of inflammatory reaction induced by TCS which stimulated the halo cells, since it is the main immune cell in the epididymis ${ }^{[45]}$.

One of TCS proposed mechanism of action is the induction of oxidative stress leading to reduction in thiol content of the cell and increasing the level of zinc thus damaging the antioxidative system ending in excess production of ROS and cell damage ${ }^{[46]}$. On the same hand, it was documented that TCS causes disturbance in $\mathrm{Ca}+$ and $\mathrm{K}$ level with an increase in cytoplasmic level of $\mathrm{Ca}+$ leading to a change in the membrane potential of the cell and mitochondrial membrane leading to mitochondrial swelling and losing of its $\mathrm{Ca}+$ and deenergization with release of $\operatorname{ROS}^{[47,48,49]}$.

In the current study, results obtained from TCSwithdrawal group revealed minimal structural changes in the epididymis, this come in agreement with some authors, who reported recovery of river biofilm community, however they stated that removal of TCS exposure for 1-2 months did not result in normal reference condition as before TCS exposure ${ }^{[50]}$. Yet other studies reported that even much lower exposure level, chronic rather than acute, and longer withdrawal period did not prove more efficient recovery ${ }^{[51]}$. Nevertheless, another study that investigated the effect of TCS on inducing mouse liver tumors and examined the possibility of recovery, stated that the gene expression and enzyme activities returned to control levels after only 14 days of recovery ${ }^{[52]}$.

Owing to the relatively few studies performed to examine the possibility of recovery from TCS exposure, the literature dose not report much on the possible mechanism involved in restoration of the near normal histological structure of the cells after TCS withdrawal. Yet this could be in part linked degradation of TCS ${ }^{[53]}$. Looking back to the data obtained from the current study, the restoration of the hormonal balance expressed as a near normal level of serum testosterone and androgen receptor immunoreactivity could play an important role in restoring the normal epididymal histology, as the testosterone deficiency and antagonists of the androgen receptor have been originally incriminated in inducing epididymal histopathological changes in the first place $^{[54]}$. The restoration of the normal cellular oxidative system after cessation of TCS exposure could also be in part responsible for the ameliorated epididymal changes, as one of the important mechanisms of TCS-induced pathology is oxidative stress ${ }^{[46]}$, yet this hypothesis remains to be examined through measuring different oxidative stress markers.

The incomplete resolution of the histopathological changes caused by TCS in the epididymis might be attributed to the fact that TCS is a mitochondrial toxic 
chemical that based on its tissue distribution and elimination, might lead to unexpected long-term toxic effects $^{[55]}$. This would encourage the incorporation of an adjuvant ameliorating agent durin the recovery period, yet some studies have suggested that a recovery period without any treatment could prove more beneficial to patients exposed to endocrine disruptors as bisphenol-A rather than the use of an adjuvant protective ${ }^{[56]}$.

Taken altogether, it could be concluded that TCS has extremely affected the epididymal lining through acting mainly as an endocrine disruptor. Withdrawal of TCS seemed to exert a satisfactory outcome. Alerts should be raised toward the widespread use of TCS in a multitude of preparations to put the proper regulations and warnings to limit its deleterious effect.

\section{CONFLICTS OF INTEREST}

The authors have no conflicts of interest to declare.

\section{REFERENCES}

1. Bedoux, G, Roig, B, Thomas, O, Dupont, V, Le Bot, B. Occurrence and toxicity of antimicrobial triclosan and by-products in the environment. Environ Sci Pollut Res Int 2012; 19(4): 1044-1065.

2. McClanahan, SF and Bartizek, RD. Effects of triclosan/copolymer dentifrice on dental plaque and gingivitis in a 3-month randomized controlled clinical trial: influence of baseline gingivitis on observed efficacy. J Clin Dent. 2002; 13(4): 167178.

3. Hinther, A, Bromba, CM, Wulff, JE, Helbing, CC. Effects of triclocarban, triclosan, and methyl triclosan on thyroid hormone action and stress in frog and mammalian culture systems. Environ Sci Technol 2011; 45(12): 5395-5402.

4. Chalew, TE and Halden, RU. Environmental Exposure of Aquatic and Terrestrial Biota to Triclosan and Triclocarban. J Am Water Works Assoc 2009; 45(1): 4-13.

5. Sandborgh-Englund, G, Adolfsson-Erici, M, Odham, G, Ekstrand, J. Pharmacokinetics of triclosan following oral ingestion in humans. J. Toxicol. Environ. Health 2006; 69: 1861-1873.

6. Barbolt, TA.Chemistry and safety of triclosan, and its use as an antimicrobial coating on Coated VICRYL* Plus Antibacterial Suture (coated polyglactin 910 suture with triclosan). Surg Infect (Larchmt) 2002; 3 (1): 45-53.

7. Allmyr, M, Adolfsson-Erici, M, McLachlan, MS, Sandborgh-Englund, G. Triclosan in plasma and milk from Swedish nursing mothers and their exposure via personal care products. Sci Total Environ 2006; 372:87-93.
8. Dayan AD. Risk assessment of triclosan [Irgasan ${ }^{\circledR}$ ] in human breast milk. Food Chem. Toxicol 2007; 45: 125-129.

9. Weatherly, LM and Gosse, JA. Triclosan exposure, transformation, and human health effects. J Toxicol Environ Health B Crit Rev. 2017; 20(8):447-469.

10. Ena, L, Lim, JS, Son, JY, Park, YJ, Lee, YH, Kim, JY, Kwack, SJ, Lee, BM, Ahn, MY, Kim, HS. Evaluation of subchronic exposure to triclosan on hepatorenal and reproductive toxicities in prepubertal male rats. J Toxicol Environ Health A. 2018; 81(11):421-431.

11. Mathur, PP and D'Cruz SC. The effect of environmental contaminants on testicular function. Asian J Androl 2011; 13(4): 585-591.

12. Dann, AB and Hontela, A. Triclosan: environmental exposure, toxicity and mechanisms of action. J. Appl. Toxicol 2011; 31: 285-311.

13. Beu, CCL, Orsi, AM, Domeniconi, RF. Structure of the lining epithelium of the cauda epididymis of the golden hamster. J Vet Med C Anat Histol Embryol 2009; 38: 49-57.

14. Hinton, B and Cooper, T. The epididymis as a target for male contraceptive development. Handb Exp Pharmacol 2010; 198: 117-137.

15. Lan, Z, Kim, TH, Bi, KS, Chen, XH, Kim, HS. Triclosan Exhibits a Tendency to Accumulate in the Epididymis and Shows Sperm Toxicity in Male Sprague-Dawley Rats. Environ Toxicol 2015; 30(1): 83-91.

16. Gaertner, DJ, Hallman, TM, Hankenson, FC, Batchelder, MA. Anesthesia and analgesia for laboratory rodents. In: Fish, RE, Danneman, PJ, Brown, M, Karas, AZ (Eds.), Anesthesia and Analgesia in Laboratory Animals. , 2nd ed. Academic Press, London (UK) 2008; pp. 239-297.

17. Gamble, M. The hematoxylins and eosin. In: Theory and Practice of Histological Techniques. Editors; Bancroft, JD and Gamble, M. 6th ed. Philadelphia: Churchill Livingstone: Elsevier; 2008; pp 121-134.

18. Jones, ML, Bancroft, JD, Gamble, M. Connective tissues and stains. In: Theory and Practice of Histological Techniques. Editors; Bancroft, JD and Gamble, M. 6th ed. Philadelphia: Churchill Livingstone: Elsevier; 2008; pp 135-160.

19. Buchwalow, IB and Böcker, W. Immunohistochemistry: Basics and Methods. Springer, Heidelberg, Dordecht, London, New York, 2010; pp. 31-39. 
20. Bozzola JJ and Russell LD. Electron Microscopy Principles and Techniques for Biologists. 2nd ed. Toronto, London: Jones and Bartlett Publishers; 1999; pp. 16.

21. Dawson-Saunders, B and Trapp, R. Basic and Clinical Biostatistics. third ed. Lange Medical Book/McGraw-Hill Medical Publishing Division; 2001; pp. 161-218

22. Cravedi, JP, Zalko, D, Savouret, JF, Menuet, A, Jegou, B. The concept of endocrine disruption and human health. Med Sci (Paris) 2007; 23: 198-204.

23. Zhu, W, Zhang, H, Tong, C, Xie, C, Fan, G, Zhao, S, Yu, X, Tian, Y and Zhang, J. Environmental Exposure to Triclosan and Semen Quality. Int. J. Environ. Res. Public Health 2016; 13: 224.

24. Zorrilla, LM, Gibson, EK, Jeffay, SC, Crofton, KM, Setzer, WR, Cooper, RL, Stoker, TE. The effects of triclosan on puberty and thyroid hormones in male Wistar rats. Toxicol Sci 2009; 107(1): 56-64.

25. Kumar, V, Balomajumder, C, Roy, P. Disruption of LH-induced testosterone biosynthesis in testicular Leydig cells by triclosan: Probable mechanism of action. Toxicology 2008; 250: 124-131.

26. Wang, CF and Tian, Y. Reproductive endocrinedisrupting effects of triclosan: Population exposure, present evidence and potential mechanisms. Environ Pollut 2015; 206:195-201.

27. Chen, J, Ahn, KC, Gee, NA, Gee, SJ, Hammock, BD, Lasley, BL. Antiandrogenic properties of parabens and other phenolic containing small molecules in personal care products. Toxicol. Appl. Pharmacol 2007; 221: 278-284.

28. Gee, RH, Charles, A, Taylor, N, Darbre, PD. Oestrogenic and androgenic activity of triclosan in breastcancer cells. J Appl Toxicol 2008; 28: 78-91.

29. Lange, A, Sebire, M, Rostkowski, P, Mizutani, T, Miyagawa, S, Iguchi, T, Hill, EM, Tyler, CR. Environmental chemicals active as human antiandrogens do not activate a stickleback androgen receptor but enhance a feminising effect of oestrogen in roach. Aquat Toxicol 2015; 168: 48-59.

30. Louis, GW, Hallinger, DR, Braxton, MJ, Kamel, A, Stoker, TE. Effects of chronic exposure to triclosan on reproductive and thyroid endpoints in the adult Wistar female rat. J Toxicol Environ Health A 2017; 80(4): 236-249.

31. Couse, JF, Lindzey, J, Grandien, K, Gustafsson, JA, Korach, KS. Tissue distribution and quantitative analysis of estrogen receptor-alpha (ER alpha) and estrogen receptor-beta (ER beta) messenger ribonucleic acid in the wild-type and ER alphaknockout mouse. Endocrinology 1997; 138: 4613 4621.
32. Witorsch, RJ. Critical analysis of endocrine disruptive activity of triclosan and its relevance to human exposure through the use of personal care products. Crit Rev Toxicol 2014; 44(6): 535-555.

33. Nguyen MM, Dincer, Z, Wade JR, Alur, M, Michalak, M, DeFranco, DB, Wang, Z. Cytoplasmic localization of the androgen receptor is independent of calreticulin. Mol Cell Endocrinol. 2009 ; 302(1): 65-72

34. Riad, MA, Abd-Rabo, MM, Abd El Aziz, SA, El Behairy, AM, Badawy, MM. Reproductive toxic impact of subchronic treatment with combined butylparaben and triclosan in weanling male rats. J Biochem Mol Toxicol 2018; 32(3): e22037.

35. Chitra, KC, Ramachandra, KR, Mathur, PP. Effect of bisphenol A and coadministration of bisphenol $\mathrm{A}$ and vitamin $\mathrm{C}$ on epididymis of adult rats: Ahistological and biochemical study. Asian J Androl 2003; 5: 203-208.

36. Takahashi, O, Ohashi, N, Nakae, D, Ogata, A. Parenteral paradichlorobenzene exposure reduces sperm production, alters sperm morphology and exhibits an androgenic effect in rats and mice. Food Chem Toxicol 2011; 49: 49-56.

37. Zhang, $X$, Zhang, $X$, Zhang, Y, Liu, M, Jin, J, Yan, J, Shen, X, Hu, N, Dong, D.. Mitochondrial uncoupler triclosan induces vasorelaxation of rat arteries. Acta Pharm Sin B 2017; 7(6): 623-629.

38. Elo, T, Sipilä, P, Valve, E, Kujala, P, Toppari, J, Poutanen, M, Härkönen, P. Fibroblast growth factor $8 \mathrm{~b}$ causes progressive stromal and epithelial changes in the epididymis and degeneration of the seminiferous epithelium in the testis of transgenic mice. Biol Reprod 2012; 86(5): 157: 1-12.

39. Yueh, MF, Taniguchi, K, Chen, S, Evans, RM, Hammock, BD, Karin, M, Tukey, RH. The commonly used antimicrobial additive triclosan is a liver tumor promoter. Proc Natl Acad Sci U S A 2014; 111(48) 17201.

40. Parlevliet, JM, Hess, MF, Pearl, CA, Roser, JF. Concentrations of testosterone and estradiol$17 \beta$ in the epididymis of the stallion and immunolocalization of androgen and estrogen receptor. Theriogenology 2002; 58:385-388.

41. Mahmoud SA and Solaiman AA. Histological study of adult male rat seminiferous tubules following triclosan administration and the possible protective role of pomegranate juice. Egypt J Histol. 2014; 37: $233-247$.

42. Zaki, MM, Ibrahem, SO, Shenouda, HD, El Salam Morsy SA, Faruk EM. Histological and immunohistochemical examination of the effect of the nonsteroidal antiandrogen \{flutamide\} on 
some organs of the male reproductive system in albino rats. Egypt J Histol. 2012; 35: 607-619.

43. Mazroa, SA. Effect of bisphenol A on the cauda epididymis of adult male albino rats and the possible protective role of quercetin: a histological and immunohistochemical study Egypt J Histol 2011; 34: 377-390.

44. Chauvin TR and Griswold MD. Androgenregulated genes in the murine epididymis. Biol Reprod 2004; 71:560-569.

45. Shum, WWC, Da Silva, N, Brown, D, Breton, S. Regulation of luminal acidification in the male reproductive tract via cell-cell crosstalk. J Exp Biol 2009; 212: 1753-1761.

46. Tamura, I, Kanbara, Y, Saito, M, Horimoto, K, Satoh, M, Yamamoto, H, Oyama, Y. Triclosan, an antibacterial agent, increases intracellular $\mathrm{Zn}(2+)$ concentration in rat thymocytes: its relation to oxidative stress. Chemosphere 2012; 86(1):70-75.

47. Weatherly, LM, Shim, J, Hashmi, HN, Kennedy, RH, Hess, ST, Gosse, JA. Antimicrobial agent triclosan is a proton ionophore uncoupler of mitochondria in living rat and human mast cells and in primary human keratinocytes. J Appl Toxicol 2016; 36(6):777-789.

48. Teplova, VV, Belosludtsev, KN, Kruglov, AG. Mechanism of triclosan toxicity: Mitochondrial dysfunction including complex II inhibition, superoxide release and uncoupling of oxidative phosphorylation. Toxicol Lett 2017; 275:108-117.

49. Popova, LB, Nosikova, ES, Kotova, EA, Tarasova, EO, Nazarov, PA, Khailova, LS, Balezina, OP, Antonenko, YN. Protonophoric action of triclosan causes calcium efflux from mitochondria, plasma membrane depolarization and bursts of miniature end-plate potentials. Biochim Biophys Acta 2018; 1860(5): 1000-1007.

50. Morin, S, Pesce, S, Tlili, A, Coste, M, Montuelle, B. Recovery potential ofperiphytic communities in a river impacted by a vineyard watershed. Ecol Indic 2010; 10: 419-426.

51. Lawrence, JR, Topp, E, Waiser, MJ, Tumber, V, Roy, J, Swerhone, GD, Leavitt, P, Paule, A, Korber, DR.. Resilience and recovery: the effect of triclosan exposure timing during development, on the structure and function of river biofilm communities. Aquat Toxicol 2015; 161: 253-266.

52. Wang, Z, Li, X, Klaunig, JE. .Investigation of the mechanism of triclosan induced mouse liver tumors. Regul Toxicol Pharmacol 2017; 86: 137147.

53. Liu, F, Ying, GG, Yang, LH, Zhou, QX. Terrestrial ecotoxicological effects of the antimicrobial agent triclosan. Ecotoxicol Environ Saf 2009; 72(1): 86-92.

54. Vidal, JD and Whitney, KM. Morphologic manifestations of testicular and epididymal toxicity. Spermatogenesis 2014; 4(2): e979099.

55. Ajao, C, Andersson, MA, Teplova, VV, Nagy, S, Gahmberg, CG, Anderssone, LC, Hautaniemi, M, Kakasi, B, Roivainen, M, Salkinoja-Salonen, M. Mitochondrial toxicity of triclosan on mammalian cells. Toxicology Reports 2015; 2: 624-637.

56. Helal, EGE, Elnemr, GM, Abdel-Azeiz, MA, Gewily DIA. Effects of Recovery Period and Tamoxifen on Bisphenol A Treated Female Albino Rats. The Egyptian Journal of Hospital Medicine 2015; 61: 529-534. 
الملخص العربى

\section{دراسة هستولوجية و هستوكيميائية مناعية و بيوكيميائية لتأثير

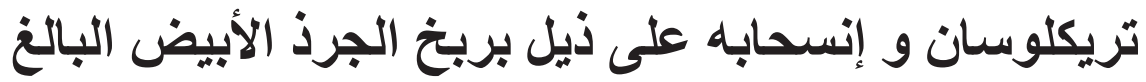

\section{رضا حسن البقرى، مروة عوض عبد الحميل إبراهيم}

\section{قسم الهستولوجيا و بيولوجيا الخلية ـ كلية الطب - جامعة طنطا}

مقدمة: تريكلوسان هو مبيد للجر اثيم مستخدم في العديد من المنتجات اليومية. من المحتمل أن يؤثر تريكلوسان على الجهاز التناسلي الذكرى من خلال قدرته على الإخلال بالغدد الصماء. الهدف من العمل: هو تقييم تأثير تريكلوسان و إنسحابه على ذيل بربخ الجرذ الأبيض البالغ بإستخدام التقنيات الهستولوجية و البيوكيميائية المختلفة. مواد و طرق البحث: تم تقسيم واحد وعشرين من ذكور الجرذان البيضاء البالغة بشكل منساوٍ إلى ثلاث مجمو عات: الضابطة ، المعالجة بتريكلوسان (عولجت 200 ملجم/ كجم/ يوم تريكلوسان لمدة 8 أسابيع) ومجموعة الإنسحاب من تريكلوسان (عولجت 200 ملجم/ كجم/ يوم تريكلوسان لمدة 8 أسابيع ثم تركت دون علاج لمدة 8 أسابيع). تم قياس كمية هر مون التستوستيرون في المصل وتمت معالجة عينات بربخية للفحص بالمجهر الضوئى والمجهر الإلكترونى. كما تم عمل صبغات هستو كيميائية مناعية بإستخدام أجسام مضادة لمستقبلات الأندروجين. برن. النتائج: أظهرت المجمو عة المعالجة بتريكلوسان إنخفاض كبير في هرمون التستوستيرون فى المصل. و أظهرت الخلايا الرئيسية فجوات تضغط أنويتها، وبعض النوى المتغلظة، والقليل من الأهداب الساكنة وقد لوحظ العديد من الخلايا الهالية قريبة من التجاويف. أظهرت البطانة الظهارية مناطق بؤرية من التطبق ومناطق من الإنقطاع. ولوحظ وجود إنساع البينية بين القنوات مع إرتشاح خلوى وبعض الأوعية الدموية المحتقنة. أظهرت صبغة مالورى الثلاثية وجود ألياف كو لاجينية بارزة تحيط بالأنابيب البربخية والأوعية الدموية وكما ظهرت زيادة فى تفاعل صبغة شيف الحمضية

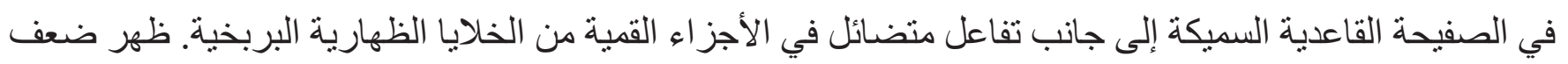
للتفاعل الهستوكيميائى المناعى لمستقبلات الأندروجين فى أنوية الخلايا الظهارية البربخية المبطنة للقنوات. أظهر الظهر فحص التركيب الدقيق خلايا رئيسية ذات أنوية غير منتظمة و تفرغ فى السيتوبلازم و العديد من الجسيمات المحللة و إتساع فى جهاز جولجى و الثبكة الإندوبلازمية الخشنة. كما لوحظ بروز ات سيتو بلازمية قمية غير منتظمة و القليل من الأهداب الساكنة. أظهرت الخلايا الواضحة بعض البروز ات السيتوبلازمية ، وحويصلات قميّة كبيرة ، و عدد قليل من القطير ات الدهنية. وقد لوحظت الخلايا الهالية مهاجرة وذات تفرغ فى السيتوبلازم. أظهرت مجمو عة الإنسحاب شكل

نسيجى شبه طبيعى. الاستنتاج: تريكلوسان قد أساء للغاية إلى بطانة البربخ من خلال العمل كعامل إختلال للغدد الصماء. الإنسحاب من تريكلوسان أدى إلى نتيجة مرضية. 